\title{
Giving Ethnic Diversity its Spatial and Temporal Meaning - Examples from Slovakia ${ }^{1}$
}

\author{
Juraj Majo ${ }^{2}$ \\ Faculty of Sciences, Department of Human Geography and Demography, Co- \\ menius University, Bratislava

\begin{abstract}
Giving Ethnic Diversity its Spatial and Temporal Meaning - Examples from Slovakia. Ethnic diversity represents one of the most accurate ways of exploring regional identity, with its temporal and spatial variations. In the methodological framework of emerging diversity studies, this paper approached the elementary forms of ethnic diversity change in regions of Slovakia in $1880-2011$ using census data and simple, yet expressive and exact, diversification indices and intercensal change. The regions of Slovakia are shown in a broad timespace analysis, with data adapted to one regional structure. Although ethnic diversity is only a minor part of a superdiversity approach and, as such, is insufficient to express the identity of a region and its population, historical and spatial data can work to provide a useful overview for the broader social analysis of a region.

Sociológia 2018, Vol. 50 (No. 6: 672-696)
\end{abstract} \\ https://doi.org/10.31577/sociologia.2018.50.6.25
}

Key words: Ethnicity; diversity studies; Slovakia; census data; regional structure

\section{Introduction}

In Central Eastern Europe, there is no unanimously agreed way in which to approach and present ethnic diversity. Do we know what it really means? How to interpret the spatial and statistical data that contain different layers of ethnic diversity? One of the possible explanations for our restrained relationship with ethnic diversity is our limited experience of it. Many countries, throughout the $20^{\text {th }}$ century, declared themselves to be ethnically 'clean', which served the goal of aiming their policies towards minorities. These tendencies were mostly an aftermath of the improper intervention of the states that supported minorities against the states they found themselves in, as the boundaries were set after 1918. The opportunity to control ethnic diversity with population migration after 1945 was welcomed, and for several decades, the issue of diversity was, at least formally, resolved.

Ethnic diversity itself, as a population character, was not eradicated nor hushed, however. It existed universally, with variability in its perception. Communist regimes operated under essentialist theories that perceived ethnic circumstances through the hierarchical levels of nations, and national and ethnic groups. (See for example Bromlej 1980) In Slovakia, the only nation was Slovak; most of the ethnic groups that had their national state were national

\footnotetext{
1 This paper was supported by grants KEGA 059UK-4/2017, and APVV 15-0184.

2 Address: Mgr. Juraj Majo, PhD., Faculty of Sciences, Department of Human Geography and Demography, Comenius University, Ilkovičova 6, 84215 Bratislava, Slovak Republic. E-mail: juraj.majo@uniba.sk
} 
groups, and ethnicities without states were ethnic groups (such as the Roma). Mutual relationships seemed established, and without contrasts in identity development.

The other issue that comes with the concept of diversity is in the awkward interpretation of its meaning for society. What does it mean for a society when it is either more diverse or more homogeneous? How can societies cope with the challenges of the changing map of identities that we experience these days? We realize that finding the answer to this complex of questions is not an easy task, but through further analysis of the temporal and spatial dynamics of ethnic diversity changes, perhaps we can gain a better understanding of its reliability as a set of complex information on a changing society.

\section{Diversity in ethnicity discussed}

One of the most challenging aspects of discussing diversity is in finding its essential meaning and a proper explanation for it in the context of societal development. We have to be aware that ethnic diversity, or diversity in general, has a different meaning in many Eastern European countries than in Western European countries. Such culturally different optics are an aftermath of a bipolar world, and differences in the magnitude of migration flows and experience of that. Ethnic diversity in Central European states represents a historical continuity of cohabiting ethnicities in one space, with changing boundaries over time. According to Kiss (1992: 62) nations in this space are historically perceived as units that are bound by a commonality of language and culture (German tradition), which do not belong to one state (political nation). The cultural roots of ethnic identity are mostly marked by language, being the most effective way of uniting a community. According to Schöpflin (1996: 103), in Central and Eastern Europe, language became the strongest instrument of mobilization by intellectuals ${ }^{3}$. One aspect of the cultural traits of ethnicity and its temporal transformation into nation is the permanent separate evaluation of ethnicity and nationality, for example in censuses. (Bačová 1992: 19)

Therefore, in the $20^{\text {th }}$ century, shifting nation boundaries helped to form minorities that now represent a mosaic, consisting of communities of various identities, spatial distributions, and different sizes, and, in many sub-regions, such minorities have formed an actual majority. Recent studies have characterized national identity, for example, as a compound of birth-place, origin of parents, and socialization. (Lášticová 2009: 46) But even in Western European countries, situations where most members of one ethnic group are concentrated in their own state is quite new, from the perspective of historical evolution.

\footnotetext{
3 "If there is a language, then its speakers constitute a community; if a community has its own language, it must be a nation; and as a nation, it has the right to constitute its own state and become a subject of history". (Schöpflin 1996: 107)
} 
(Šatava 1994: 14) In practical terms, the ethnic diversity issue in Slovakia is discussed as a political issue, for example in the underrepresentation of local minorities in regional government, and aspects of sustaining minority language education and its public use. (See for example Buček 2001)

Considering diversity, we have to realize, as Vertovec (2015: 10) proposed, that diversity studies are not about celebrating, or promoting a picture of, an ideal societal cohabitation of identities, but rather they are an approach to understanding how modes, mechanisms, and outcomes of social differentiation work. As far back as 1982, diversity lacked "formal definition, logical development as a concept and its measurement" (Patil - Taille 1982: 548), and still today, diversity is more or less still without specific conceptualization and theories, so it comes "without baggage" (Vertovec 2015: 4), or can be labelled as a "tofu-term", since it has no flavor until it marinates in an institution-specific sauce. (Price 2014: 1) Diversity should be seen as "legitimate discursive space" in which people from various positions and backgrounds live and express their identities (Arnaut 2012: 7), or as "heterogeneities along the boundaries" (Faist 2015: 265), but definitely seeing diversity in terms of ethnicity only is not sufficient; it needs to accommodate more variables (Vertovec 2007: 1025), some of which are discussed and further outlined below. Such a 'superdiversity' (a concept elaborated by Vertovec 2007; Arnaut 2012; Crul 2016 etc.) approach seems to be the best way to grasp all aspects of societal internal heterogeneity and the different identity intersections. As ethnic diversity might be connected to either religious or linguistic backgrounds in different parts of the world, to provide a more exact platform for grasping societal diversity, a social diversity index was developed. (Okediji 2005) ${ }^{5}$ Patricia L. Price (2014: 5) called for "diversifying diversity" that should occur in geographical research and policy, including several variables (sexuality, physical ability, age, marital status, etc.) that should be added into diversity policies to make them more inclusive of diversities, beyond racial and ethnic categories, as people of various ethnic backgrounds belong to various demographic and socioeconomic structures as well (age, religion, employment, etc.). (Piekut et al. 2012: 3005) From certain aspects, different social identities can be highly comparable in their expressions. For example, ethnicity and class identity are similar in their power differences and rivalry in public space, but, as class membership can be

\footnotetext{
${ }^{4}$ We consider ethnicity as a tofu-term as well. Although being a member of one imagined community, ethnic identity gains its meaning in a broader social context within a spatial and temporal framework. Considering ethnicity as the only explanatory factor is definitely insufficient but should work as a view through which the social processes and structures can be analyzed.

5 The social diversity index encompasses the numbers of linguistic, racial, and religious groups in the country. Each group is treated independently, so it allows the discovery of regional variations of ethnic identity and takes into account the individual branches of religion to cover potential conflict inside the society. The Eastern European countries, however, were not included in the calculations in this paper.
} 
changed by social mobility opportunities, ethnicity is, for many people, more difficult to change. (Eriksen 2008: 326-327)

Several studies have tried to find internal aspects and a mutual relationship between ethnic diversity and social development. Experience from Africa was presented by Easterley and Levine (1997), who claimed that ethnic diversity is not strongly connected to every economic indicator, but that some of these are noteworthy: high black-market premiums, low education level, or low provision of infrastructure (1206 - 1207), ethnic diversity likely increases the possibility of adopting poor policies, and underproviding growth-enhancing public goods (1213). The findings of Posner (2004: 861) revealed that, in Africa, ethnic fractionalization is negatively related to economic growth and, as Okediji (2005: 852) found, that one formula does not reveal the potential for more ethnic cleavages. The French experience concerning housing outlined a relationship between diversity and generating social anomy, leading to higher levels of vandalism (Algan et al. 2016: 721), a negative effect of diversity on local public goods in the public housing sector (2012: 28), or no correlation between diversity and quality of public spaces and local transport (2012: 21). Collier et al. (2001) saw ethnically diverse societies as those that would find cooperation difficult, potentially leading to dysfunctional politics and violent civil conflict, or even war, although he indicated that the ethnically diverse population was not economically worse off, and counted Slovakia among those states that, after the Cold War, there was a tendency to form small ethnic states (153). Schneider and Wiesehomeier (2010: 1111) highlighted that we should be careful when interpreting causalities of fragmentation and social development because, "while fragmentation might lower the risk of one form of violence, it can increase the propensity of another form of violence; and while polarization might affect economic development given a certain institutional configuration, it might not do so in all contexts".

One of the most crucial aspects is spatial segregation of ethnic communities in various environments (especially urban space). (See for example White 1986; Wong - Shaw 2011; Musterd - van Kempen 2009) Ethnicity seems to be the main cause of such segregation, but many times it is more connected with social status. Guest and Weed (1976: 1011) proved, in several cities and metropolitan areas in the U.S., the positive relationship between difference in social status (especially income level) and difference in residential segregation patterns (1976: 1011). The segregation seemed to be the result "of a combination of self-choice and the discrimination of the larger community" (1976: 1103). A more recent study, from Leeds, U.K. (Stillwell - Phillips 2006), also pointed at the role of social class in shaping the distribution of ethnic groups in the city (2006: 1144). Such communities were formed in the city not just due to poverty, but also due to the desire for community living, support, proximity to 
community organizations, and the effects of housing and job market discrimination (2006: 1149). In the Slovakian context in recent decades, there appears to be the most practical application in the case of segregated Roma communities, either in cities or rural settlements ${ }^{6}$. In certain parts of Slovakia, they make up a major contribution in current ethnic diversity.

\section{Methodological aspects of diversity analysis in Slovakia}

If we want to combine the spatial and temporal data on ethnic diversity thoroughly, we need a robust dataset. We have been using the ethnic data from Slovak communes, recently published in a Slovak archive of social data. The original approach in this field began in 2012, with the publication of a historical-demographic gazetteer of Slovakia (Majo 2012), consisting of ethnic and denominational data on each Slovakian commune from 1880 - 1910. Later, the data were revised and completed with following censuses from the years 1921 - 2011. (Majo et al 2017) The data on communes allowed various forms of aggregation into regions (districts). This aggregation was maintained for all censuses, providing us an excellent platform for temporal comparison. Due to the unity of comparisons, we calculated data for administrative division in 2011.

Ethnic diversity as such can be discussed as a variable and ongoing or even fluid phenomenon, however, the quantitative interpretations in temporal and spatial framework allows to underpin this process with more exact data. There are several statistical methods how to interpret diversity and how to see its figures as a helpful and solid argument for further analyses. Exact measurement of diversity of population can be found in many forms and papers. (See for example Lieberson 1969; Posner 2004; Warf - Vincent 2007; White 1986; Yeoh 2003) In this paper we were aimed at spatial and temporal aspect at once. We have chosen one type of identity measurement that has already been used in our cultural context and might appear more familiar. Its application may confirm or challenge the way how the ethnic diversity is sustained in current discourse providing longer time period. For each district and each census, we calculated the so-called Piasecki diversification index. The formula was introduced by Piasecki (1964) and contains the squares of individual ethnic group counts and a square of the whole population count:

$S=\frac{n_{1}^{2}+n_{2}^{2}+\cdots n_{k}^{2}}{N^{2}} \cdot 100$,

where $n$ represents the size of ethnic group 1, and $N$ represents the whole population as a statistical unit. The value can vary between 0 and 100 , where 100 means total homogeneity, and 0 total heterogeneity. This formula has been

${ }^{6}$ See, for example, Mušinka et al. (2013). 
used, for example, in the works of Häufler (1976), Siwek (1996), Majo Horňák (2007), Majo - Šprocha (2016), and Durček - Šprocha (2017) mostly for ethnic population structure. The temporal aspect of ethnic diversity change was calculated as a sum of the absolute values of the index values' differences between censuses. It was aggregated for the whole period as such (1880 2011, which included 12 censuses), and for specific time periods covering key periods in the history of Slovakia and Central Eastern Europe (such as the disintegration of the Austro-Hungarian empire in 1918, the advent of Communism after 1948, and the end of this period in 1989) ${ }^{7}$. Cumulation of the absolute values, as such, does not indicate whether the region underwent homogenization or heterogenization of its ethnic diversity, but does indicate the scale of such change, and the dynamics or stability of individual regions in a temporal and spatial perspective. Cartographic interpretations of intercensal aggregations of diversity indices and their absolute value differences were sorted and its map depiction is limited to the two most notable intervals ${ }^{8}$.

There are several further issues that should be taken into account when considering ethnicity measurement in Slovakia.

1) Measurement of ethnicity varies over time. In years 1880 - 1910 we derived ethnicity data from mother tongue data. Censuses carried in these times were not directly aimed at own identity expression. (See for example Arel 2004: 96) In 1900 and especially in 1910 Austro-Hungarian census, the question on identity was altered to the language the respondent speaks the best or love to speak the most. (Czibulka 1999: 34) Since 1921 the censuses contained question on ethnic affiliation, although especially in $1921-1930$ its expression was indicated by mother tongue and in later censuses the bond between mother tongue and ethnicity was more released as its declaration became a subject of a free declaration. (See for example Šprocha 2014a: 186-187)

2) There is an unsolved issue of double identities. It is an uneasy task to estimate the number of such individuals, as censuses do not enable to express two or more ethnic identities. We presume, that especially in contact regions its number can be quite high as the heterogamy level there is now higher than it used to be in past.

\footnotetext{
7 The first period, 1880 - 1910, includes the 1880/1890, 1900/1890, and 1910/1900 census data calculations, the second, 1910 - 1950, includes the 1921/1910, 1930/1921, and 1950/1930 census data calculations (1940 was not available or processed yet for the whole territory of Slovakia), 1950 - 1991 includes the 1970/1950, 1980/1970, and 1991/1980 census data calculations, and 1991 - 2011 includes the 1991/1980, 2001/1990, and 2011/2001 census data calculations.

${ }^{8}$ Regions were ordered according to the aggregated diversity index difference value. Districts above a value of $50 \%$ and below $75 \%$ of the cumulative count of the sum of the difference values of a respective period were sorted into the first interval (notable diversity change), and those above $75 \%$ were sorted into the second interval (the most notable diversity change). This is an adjusted method used by P. Jehlička, and L. Sýkora (1991).
} 
3) Specific aspect of ethnic identity measurement are Roma populations. Although there are no objective criteria to determine the Roma identity (Messing 2014: 816), the problem with identifying this issue, according to the official census data, is the discrepancy between identity ascribed by majority, usually based on inherited and socially constructed anthropological and behavioral perceptions, and official census data. Ascribing the identity was even used by enumerators at the 1970 and 1980 censuses, where they were entitled to ascribe Roma identity according to "own evaluation". (Vaňo 2001: 7) It is now estimated (Šprocha 2014: 13), that official censual data represent about $1 / 4$ of the Roma population in Slovakia.

4) 2011 census was very specific due to several failures in counting many individuals and filling out their questionnaires. Especially in cities, many individuals refused to be counted, or were not even visited by a census inspector. In Bratislava, for example, several ten thousand inhabitants were not participating at the census 2011. (Benkovičová 2014: 15)

\section{Slovakia's diversity through time}

One of the most notable aspects of diversity variability is its stable progress towards homogenization of its ethnic composition. Slovakia's starting diversity index value position in 1880 was less than 50 for the entire country, which could be interpreted as a rather heterogeneous space. A very heterogeneous landscape, that is still in certain form preserved today, was in Eastern Slovakia, where, historically, several identities met and cohabitated for centuries, the ethnic diversity being also underpinned by religious and economic diversity. This diversity was influenced by certain political and social aspects. In particular, the identity of mainly the Eastern Slovakian districts, with a Greek Byzantine Church majority, was complicated, as a major characteristic of their identity was religion, and then their region of residence. Only the bottom layers of their identity were of either Slovak or Ruthenian ethnicity. (Švorc 2005: 188) Studies from the period before modern censuses (before 1869) indicate that there were communities consisting of three or more language sub-communities. (Šoltés 2009: 146) Moreover, in this boundary region, the process of selfidentification as 'Carpathian Slavs-Ruthenians' was never accomplished, due to low levels of literacy, distance from cultural centers, and lack of intellectual leaders, which promoted an internal ethnic heterogeneity of the Ruthenians. (Duleba 2005: 114) Here, we find the most heterogeneous region in 1880 (apart from the Bratislava and Košice urban regions) - the Stará L'ubovňa region. This region had no particular relative ethnic majority, and almost equally (40\%) consisted of Slovaks and Ruthenians. A similar makeup in Eastern Slovakia had the Gelnica region consisting of Germans (46\%) and Slovaks (37\%). The 
stability of this ethnic composition remained intact until 1918, and changed noticeably only in the $1930-1950$ period.

The diversity indices continued to show an inclination towards homogeneity until 1900; however, this was a very slight change that consisted mostly of a stable increase in the proportion of Hungarians (22\% in 1880 to $27 \%$ ), then stability, or a slight increase of Slovaks and, finally, a relative decline in Ruthenians and Germans. More extensive changes in ethnic diversity were bound to different transformations, mostly in the areas of industrialization, or their growing importance as a transportation node for broader-scale immigration. (See Figure 1)

As a consequence, the diversity indices changed as well. For example, the Zvolen region (growing in importance as a transportation node) in Central Slovakia, had an increase in the population of Hungarians from 3.1\% in 1880 to $17 \%$ in 1910, whilst the entire population of Zvolen region increased by almost $30 \%$. Diversity changes in other regions were not always connected to the changing positions of the industrial centers. For example, in Eastern Slovakia, the diversity level in the Sabinov region changed noticeably due to a growth in the proportion of Hungarians and Ruthenians in 1880 - 1910, alongside a decrease in Germans, while the size of the population in this region shrank overall. In the most dynamic region in Eastern Slovakia - in Sobrance - the source of transition was similar. Many settlements with a Slovakian majority in 1900 became villages with a dominance of Ruthenians by 1910 . These villages had returned to their former ethnic makeup by the 1921 census. Very specific trends took place in the Tvrdošín region that is now a neighboring region with Poland. The sources of the diversity shifts were embodied in changes in several communities, where, according to the 1900 census, the population declared themselves to be Slovaks and, in 1910, as 'Other', probably Poles. Such small, and relatively unimportant, forms of 'statistical extravagance' positioned Tvrdošín as one of the regions with the most dynamic change in ethnic diversity in Slovakia in $1880-1910$. 
Figure 1: Cumulative absolute values of the change in intercensal ethnic diversity indices, 1880 - 1910

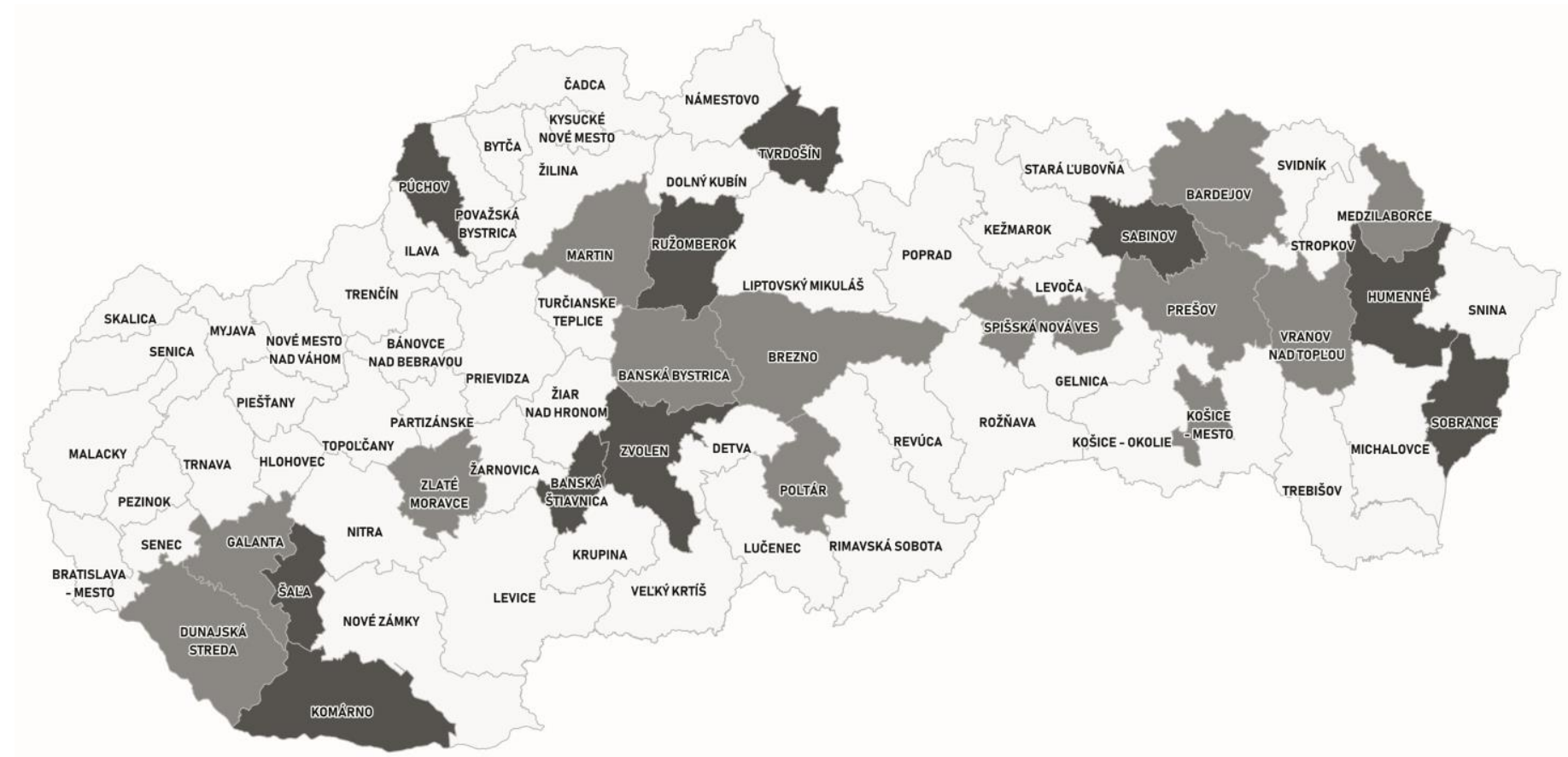

notable diversity change

the most notable diversity change

Source: Majo et al. 2017, own calculations. 
The census data of 1910 have been challenged many times in Slovakian historiography as being not very reliable. Many times, the data depict the results of so-called statistical magyarization ${ }^{9}$, which portrays an intense change in ethnic proportions towards rising numbers of Hungarians and a decreasing proportion of Slovaks. In terms of diversity, it could represent variation of the ethnic landscape in hitherto rather homogeneous regions. The change, however, was not that dramatic, if we take a closer look at the data from the 1880 and 1910 censuses, as the highest intercensal difference between diversity indices was recorded already in $1890-1880$. The heterogeneity index between the two points in time is almost the same (43.3 in 1880 and 43.2 in 1910). In a slight majority of regions, the diversity index inclined towards homogenization, and most of the regions with growing heterogenization in $1880-1910$ were featured with an increase in Hungarians and a decrease in Slovaks and other ethnicities. Generally speaking, in the time of peak magyarization, the proportion of Slovaks did not decrease in every region, but in around one-quarter of the regions; the proportion of Slovaks in 1880 - 1910 even increased. These were the regions mostly located in areas where the concentrations of Hungarians had not been numerous yet.

Not all ethnic diversity transitions were connected to the heterogenization of the ethnic composition of the regions. In certain cases, the dominant ethnic group cemented its statistical prevalence and grew in its relative numbers. There are two examples: the Púchov region in Northwestern Slovakia, which was the region where, especially in $1880-1890$, the proportion of Slovaks increased at the expense of the German population. Similarly, the Komárno and Šal'a regions in southern Slovakia saw a relative increase in Hungarians and a decrease in the population of 'Others'.

\footnotetext{
${ }^{9}$ Statistical magyarization represents the intercensal increase in Hungarians and decrease in Slovaks in the current territory of Slovakia in 1880 - 1910. This process was described, for example, by Svetoň (1941), who provided data and arguments that it was not a natural process of ethnic change, since the data on out-migration and natural increase should result in a more robust increase in the relative and absolute numbers of Slovaks, and not a decrease. Granatier (1930) provided a list of communes with abrupt intercensal changes in the ethnic composition of many communities in southern Slovakia. The historian Mésároš (2004) provided examples of several communities with vast intercensal changes in the proportion of Slovaks and Hungarians, many of which were located along the Slovak-Hungarian ethnic boundary in southern Slovakia. Holec (2012) agreed with the fact that the increasing number of Hungarians could have not been the result of natural assimilation, but that a significant factor was a change in a question in the census that, in 1910, shifted it from the mother language to a "language you consider your own and which you like and speak the best". (Holec 2012: 89) On the other hand, magyarization supported by the State resulted in "defending reactions of Slovaks and unwittingly helped to build and cement Slovak national identity" (2008: 135).
} 
Figure 2: Cumulative absolute values of the change in intercensal ethnic diversity indices, 1910 - 1950

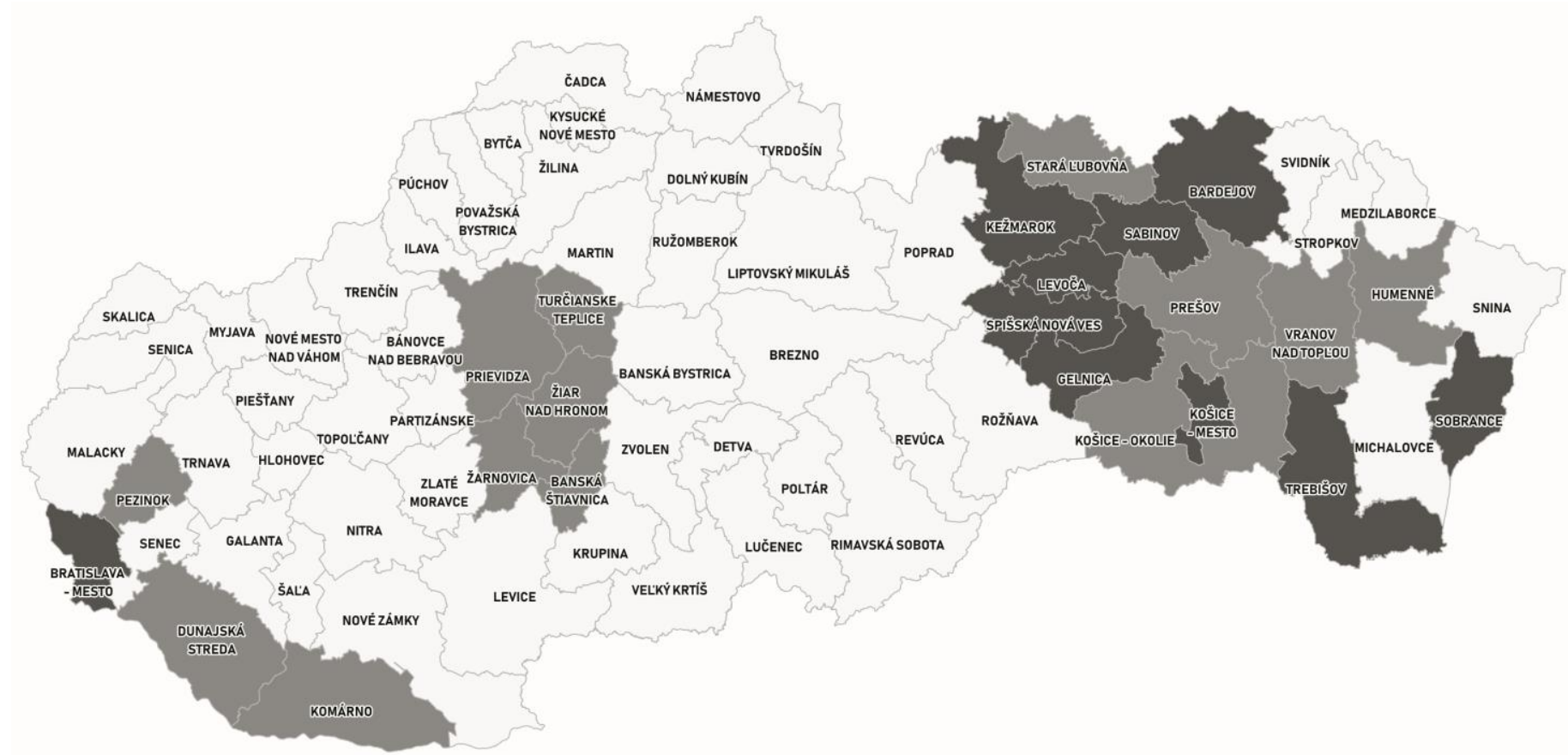

notable diversity change

the most notable diversity change

Source: Majo et al. 2017, own calculations. 
Major diversity changes took place in $1910-1950$ period. This is the time of vast ethnic changes almost everywhere in Slovakia. The most dramatic changes did not take place in 1910 - 1921, as a result of the formation of new states, but in $1930-1950$, as a result of the robust ethnic changes and processes that swept across the former ethnic landscape. Historian Dušan Kováč described this period as a time when the "minority refused to declare itself as a minority, but felt connected with the nation that usually lived in a neighboring state". (Kováč 2009: 282) In interwar Czechoslovakia, this was the case of the Hungarians and Germans. The homogenizing process of $1910-1921$ was intense in regions that had become centers for an increasing concentration of Hungarians in previous times; historically, they were an allochthonous element there, connected by structural changes in industry, for example (cities such as Zvolen, Martin, Banská Bystrica, Banská Štiavnica), or the concentration of Hungarians was in urban settlements in these regions. The years $1921-1930$ were marked by an increasing concentration of Czechs and Slovaks in the region, among a Hungarian majority (increased heterogeneity in the Dunajská Streda and Komárno regions), or Ruthenian majority (such as Medzilaborce in Eastern Slovakia).

The 1930 - 1950 period can be labeled as the time of the most intense ethnic change in Slovakia's modern history. The value of the diversity index is more than three times higher in 1930 - 1950 than in $1910-1921$. There were only few regions with a small ethnic diversity change. Major progress toward homogenization of ethnic diversity then took place in regions with a formerly greater proportion of Germans, especially in Eastern Slovakia, or regions where Hungarians and Ruthenians decreased. (See Figure 2) In a few regions with almost homogeneous ethnic composition, minor changes towards heterogenization were seen.

The advent of Communism after WWII obviously did not have much of an impact on the ethnic landscape. Firstly, the major ethnic changes that were the starting point towards homogenization, occurred during WWII, or slightly after, in 1945 - 1947. As Germans and Hungarians were forced to leave Czechoslovakia, the diversity leaned towards its more stable direction. After 1948, nationality (ethnicity) politics were subordinate to the decisive role of the Communist Party. This meant that potential conflicts were solved by authoritative political power, and many problems were oversimplified, or even criminalized, being labeled as hostile activities against the Party and the State. (Šutaj 2005: 8) In Census 1950, the number of Hungarians, for example, reflect the postwar trauma of "years without a homeland" with notably high decrease of Hungarians. (Gyurgyík 2008: 156) From 1950, the diversity index does not fall below 74 out of 100 . Although the 1960 census data was not available, the trends in the demographic profiles of the major ethnic groups, associated with 
the generation of baby-boomers, moved towards greater ethnic diversity in 1970 (74.6), but then, the value returns to its former level (76 points). In 1950 1970 , in several regions, the number of Slovaks even decreased, while the number of other ethnicities increased. In the Vel'ký Krtíš (South-Central Slovakia) and Trebišov (Southeastern Slovakia) regions, the number of Hungarians increased, whilst Slovaks decreased, which put these regions into the set of regions with the most notable ethnic heterogenization during the first two decades of Communism. Ethnic change in northeastern regions (of a similar degree to Southeastern Slovakia) - Svidník, Stropkov, for example - was toward homogenization, where the number of Ruthenians and Ukrainians decreased, as the number of Slovaks increased. The homogenization process was also evident in the Dunajská Streda region, with its majority of Hungarians. Here, the number of both ethnic groups (Hungarians and Slovaks) increased; however, the increase in the number of Hungarians was higher, which cemented the overwhelming Hungarian character of this region. (See Figure 3) In 1960s, according to J. Botík (2006: 76) majority of the Hungarians lived in rural communes, and around $40 \%$ were employed on agricultural farms in the communities of their residences, which helped to sustain their ethnic vitality. The general intensity of the homogenization process in the ethnic makeup of Slovakia is evident from the diversity indices: in 1930, there were only 11 regions with an index value over 95, going to 34 regions in 1950, and 39 regions in 1970. The explanation for such a growth of non-Slovakian ethnicities resides in the notion of a "consolidation of societal circumstances...new economic resources are equally distributed among all regions in the Slovak Socialist Republic, and newly emerging social and interpersonal relationships are helpful in building current integration process in our society". (Mazúr 1974: 456-457)

Overall ethnic change from $1950-1991$ peaked at its highest intensity in 1950 - 1970. In later years, until the end of Communism, there were no significant issues that would change the ethnic structure of the population. Regions in Eastern Slovakia, however, seemed relatively dynamic in $1970-1980$. In one part of Slovakia, there were regions with both the biggest ethnic homogenization and heterogenization at one time. For example, the Medzilaborce region was already a depopulating region at this time, but while the number of Ruthenians decreased, the number of Slovaks increased, which made the landscape more heterogeneous. In nearby Bardejov region, the whole population increased, making this region more homogeneous. We must point out that the emerging and increasing number of 'Other' (mostly Roma, who were not evaluated separately), was the most salient heterogenizing agent at that time. 
Figure 3: Cumulative absolute values of intercensal ethnic diversity indices' change in 1950 - 1991

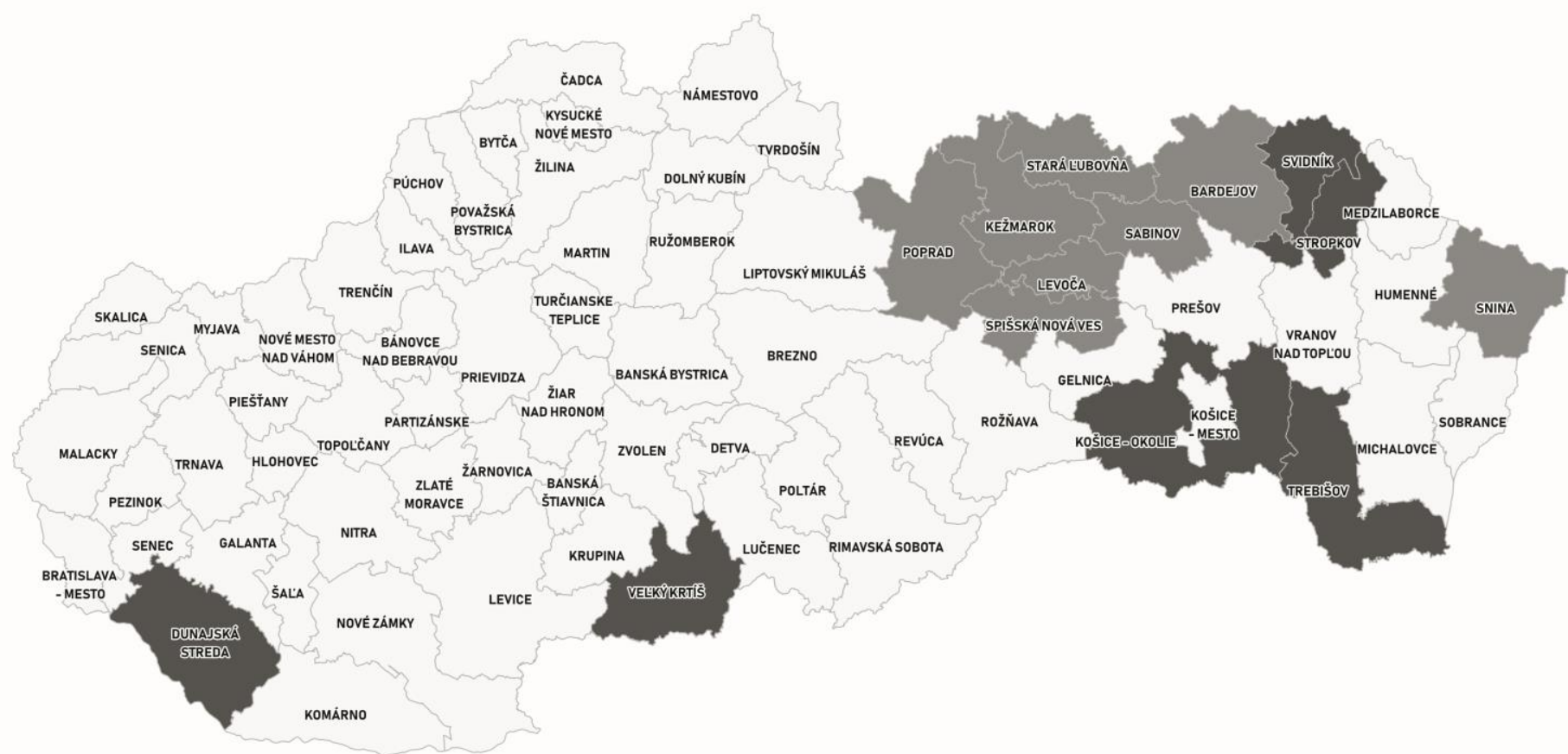

notable diversity change

the most notable diversity change

Source: Majo et al. 2017, own calculations. 
Social and political changes after 1989 also influenced the ethnicities in many respects. The situation changed in the case of ethnicities that were not considered as fully recognized ethnic groups, and which had not been evaluated in previous censuses. One such group were Roma. They belong to one of the categories that have caused the major diversification of ethnic structure in Eastern Slovakia. This does not mean they were not present before 1990, only that the option to declare one's own identity freely did not appear on the census until that time. Regions exclusively in Eastern Slovakia saw significant diversification: Spišská Nová Ves -98 points to 83.7 , Gelnica -98.5 to 86.4 , and Sabinov 98 to 87 points, in 1980 - 1991. Generally, the increase in numbers of Slovaks and Roma was seen also in the numbers of Germans, Hungarians, and Others, while a decrease in numbers was seen in Ruthenians (partly due to their shift to a Ukrainian ethnicity), and those who did not declare their ethnicity. In the 1990s, studies on the diverse regions in Eastern Slovakia, and their potential ethnic tensions, showed that there was no crucial difference in perception of ethnic tension between the respondents residing in ethnically more homogeneous or heterogeneous communities (Ira 1996: 26); moreover, various ethnic and religious identities could, according to respondents, reside in one region peacefully. A similar attitude was adopted by Podoba (2009: 583-584), who, claims with generalized view that, in ethnically diverse regions with an almost daily interethnic contact, there is a lower possibility for conflict, but there are special exceptions in some communes with a high proportion of Roma. Generally, the dynamics of ethnic changes after 1990 reflected social changes in society. Such changes have been considered to be ethnic and national mobilization, with attempts for "segmentation, autonomy, cultural pluralism encouragement, just like cultural similarity underlining or homogeneity of nations (ethnic groups)”. (Bačová 1992: 23)

The period $2001-2011$ embodied certain changes that require further explanation, although the diversity level between 1991 and 2001 remained the same. The intercensal change in the proportion of Undeclared increased, while the proportion of Other decreased. As major changes in the size of the ethnic groups happened mostly to the Roma and Ruthenians, the archipelagos of ethnically changing regions was mostly in Eastern Slovakia. (See Figure 4) Only in 2001 - 2011 has the source of major change in the ethnic breakdown been in the increased number of Undeclared. In the city of Košice, the diversity index, due to such change, dropped by more than 21 points (80 in 2001 to 58 in 2011); however, as the tendency to not declare ethnicity has spread over the country, there was no region in $2001-2011$ with an increased diversity index. Many times, the number of Undeclared has increased notably in homogeneous regions, therefore the value of the diversity index difference seems very vivid. (For example, in some Western Slovakian regions - see Figure 4.) 
Figure 4: Cumulative absolute values of the change in intercensal ethnic diversity indices, 1991 - 2011

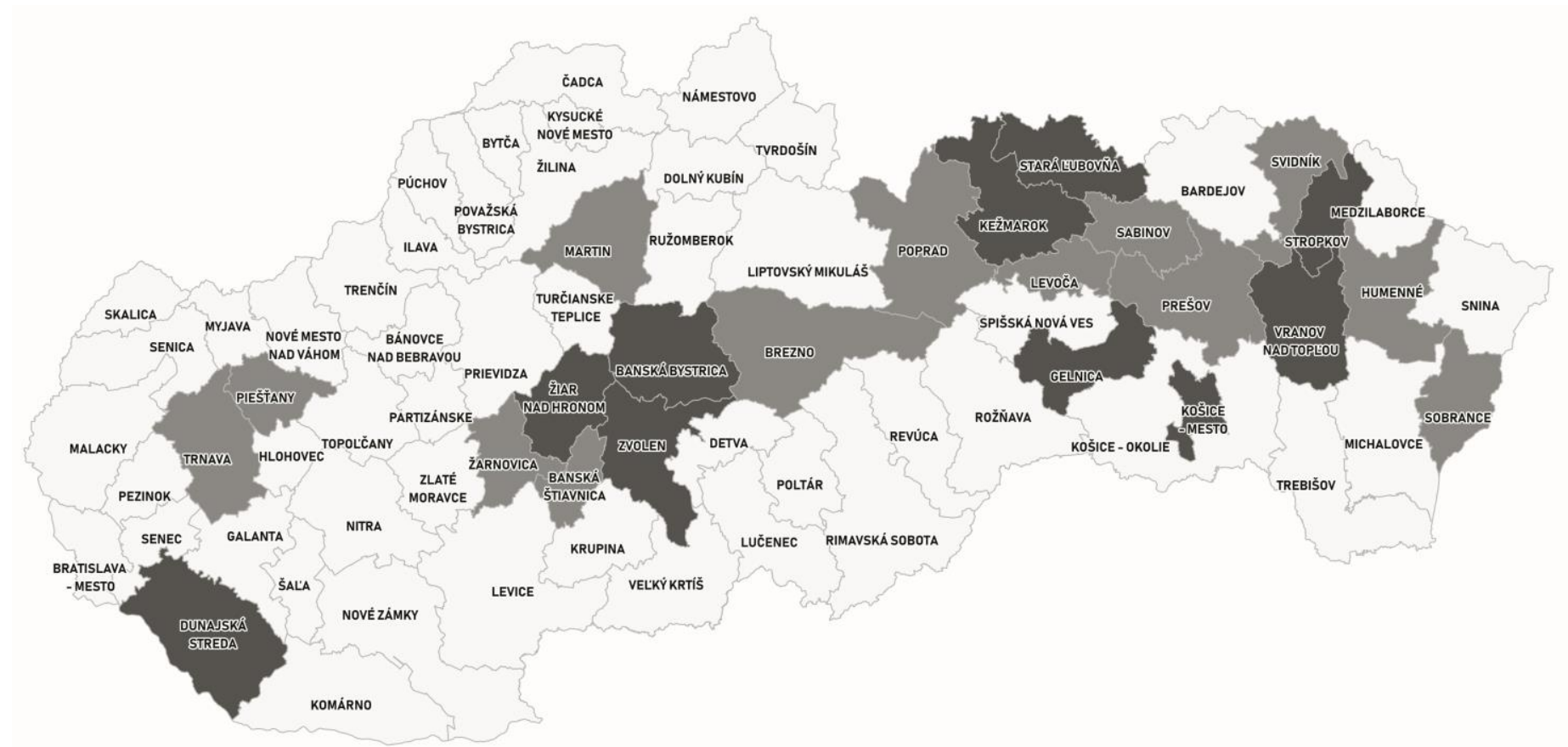

notable diversity change

super notable diversity change

Source: Majo et al. 2017, own calculations. 
We can be sure that the ethnic diversity is not a mere result of natural or migration increase or decrease. Moreover, such demographic processes seem to stand at the back, while other, mostly political issues, tend to form the ethnic landscape more. Particularly in the case of Central Europe, such changes were present throughout the whole $20^{\text {th }}$ century. In the course of the diversity index change, we can see two notably different periods. The first is $1880-1950$, the second 1950 - 2011. (See Figure 5) These potentially indicate that the political regime after 1950 considered the ethnic circumstances as solved, and so there were no extraordinarily striking moments in the ethnic history of Slovakia from then on. But the stability is not, in this case, a sign of pacification. It is simply the result of the vast changes in 1940 - 1950 that completely purged Slovakian ethnic figures, creating apparent stability, homogeneity, and peace.

Figure 5: Distribution of regions in Slovakia according to their ethnic diversity indices in 1880, 1930, 1970, and 2011

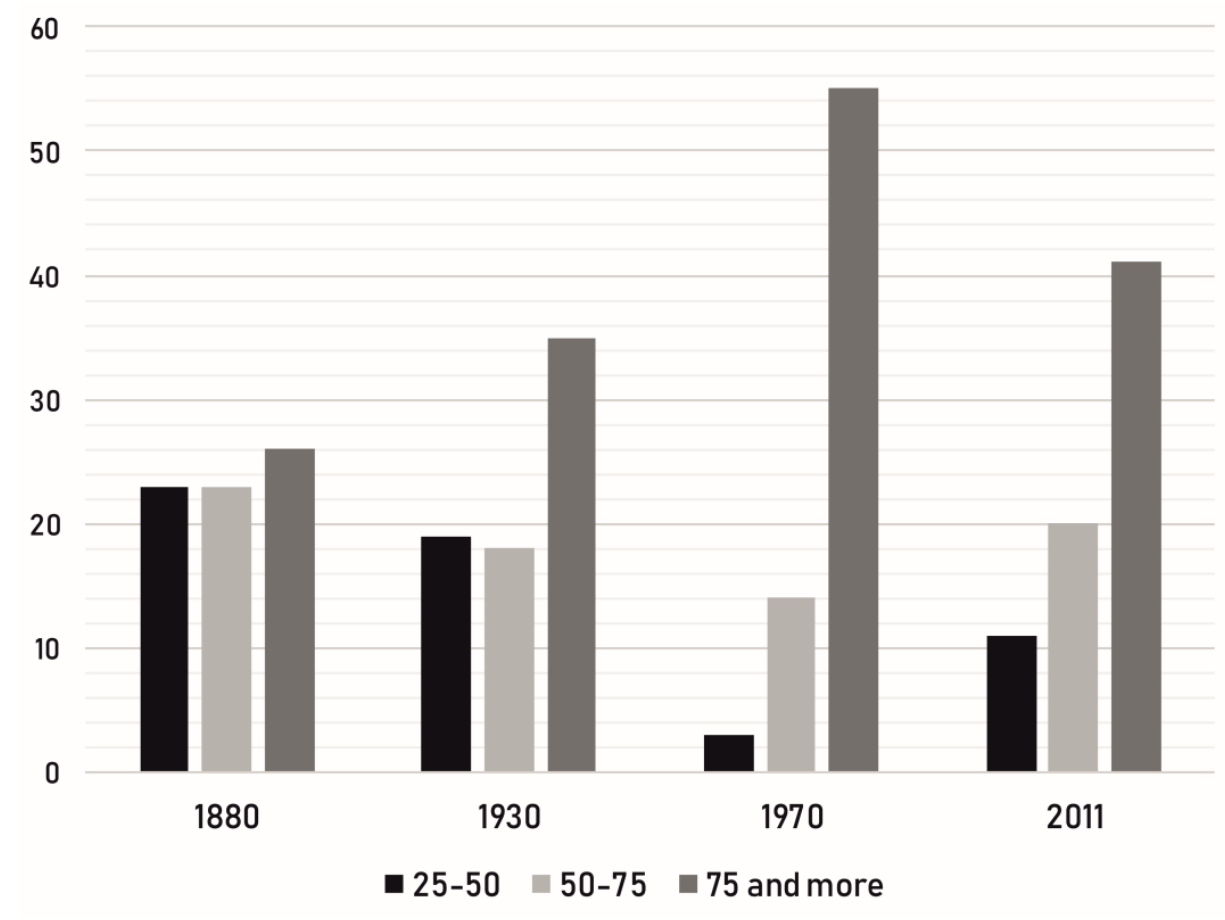

Source: Majo et al. 2017, own calculations.

In overall terms, the dynamics of ethnic structure in Slovakia between 1880 and 2011 represent homogenization of the ethnic landscape. Herein, it has been shown that diversity change is generally intertwined with changes in another 
social, or even economic, structures (mostly religion, or economic activity, or simply just migration flow and the rise in urban populations). The group of most stable regions was generally stable during the entire period, and different aspects of their landscape did not change much (especially the proportion of people with declared religious affiliation). These regions remained off the beaten track of industrialization vectors, but they were, and are, steady in their population growth, especially up to 1991. (See Figure 6) As mentioned above, such regions are mostly in Northern Slovakia, some in Western and Central Slovakia. Several relatively stable regions, from the ethnic point of view (Myjava, Revúca), however, underwent certain changes in their religious landscape (in terms of secularization; see Majo, 2013), or slight population stagnation, or decline in more recent times. The most dynamic change happened in three Eastern Slovakian regions (such as Sabinov, Kežmarok, Gelnica). The diversity dynamics of Sabinov, for example, are explained by so-called 'censual turbulence', where, in many cases, the index changed between censuses quite rapidly, mostly due to dynamic numbers of Slovaks and Ruthenians. The cumulative impact of such changes is therefore quite high, but they do not encompass sudden ethnic change, as in the other most dynamic regions (Kežmarok, Gelnica). The source of the most dynamic impetus in these two cases emerged in $1940-$ 1950.

Dunajská Streda and Komárno are two regions in Southwestern Slovakia that have a slightly different story to the Eastern Slovakian regions. These are two regions that underwent the most significant heterogenization of the ethnic landscape in 1880 - 2001. In particular, the cumulative value of the ethnic change in Dunajská Streda is at a similar level to that of the most dynamic regions in Eastern Slovakia. These two regions underwent the most notable change in 1910 - 1950, while in other periods, the intercensal values are quite balanced. But the heterogenization of mostly Hungarian regions was one of the most notable. This region has been in the political discourse particularly since 1990, being quite sensitive to minority issues and the Slovakia-Hungary relationship. Sutaj (2012: 302) saw this region as “...ideal space for assimilation processes. Slovaks and Hungarians lived next to each other for long centuries. There exist direct connections among cultures, such as vernacular architecture, cuisine, folklore, and lifestyles." Central Slovakian districts reflected changes connected with German population displacement and changes after 1990. 
Figure 6: Change in overall cumulative absolute values of intercensal ethnic diversity indices, 1880 - 2011

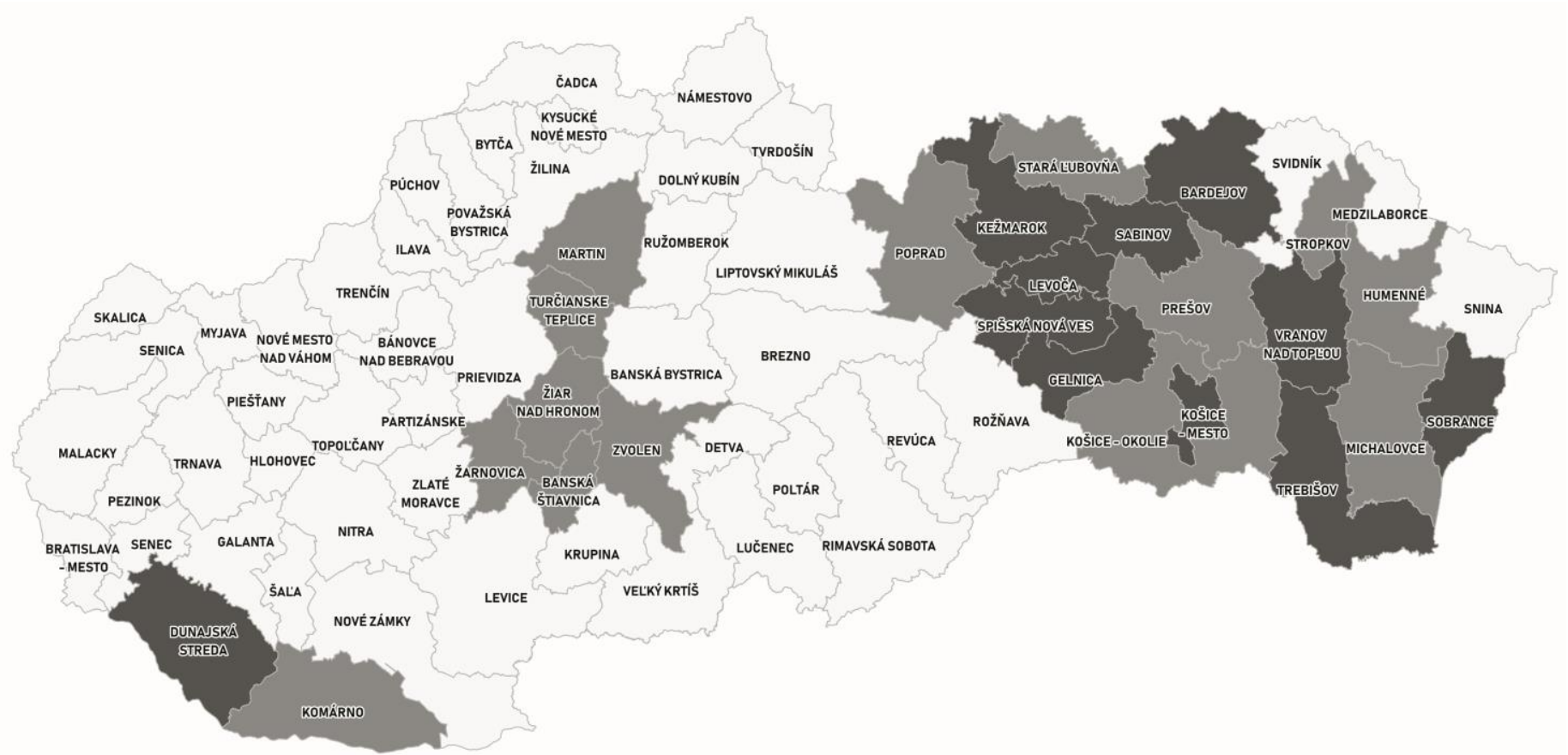

notable diversity change

the most notable diversity change

Source: Majo et al. 2017, own calculations. 


\section{Discussion and concluding remarks}

We are fully aware that perceiving ethnicity through census data, with all its different methodologies, is of course not an exhaustive form of research. Moreover, quantitative analysis of ethnicity is strongly reductionist, as the "interpretation of results is cognizant of the limitations of this kind of categorization" (Brown - Langer 2010: 415), but for such a spatial and temporal examination, there is no better data. This analysis is therefore just a 'shallow immersion' into the diversity approach of studying the Slovakian ethnic landscape of the past 140 years. So, despite having several imperfections, such an analysis can summarize the situation, and allow us to ponder upon several issues.

Major changes in ethnic diversity, especially in the $20^{\text {th }}$ century, were not always an aftermath of a progressive societal change, and the transformation of ethnic groups through ethnic processes (such as assimilation, intermarriage, etc.), but were rather the result of sudden ruptures in regions where ethnic groups were literally eradicated with almost overnight velocity. And aftermaths? Such abrupt changes in human resources can influence regional stability and development. Certain spatial interpretations of marginality might indicate some intersections between economically deprived regions and regions with the largest ethnic diversity change. (See for example Korec 2014; KorecRusnák 2016) As the Roma ethnic group is, in current discourse, seen as a socially marginal group, in many cases its growing presence in higher numbers in certain regions is interpreted as one of the most hampering vehicles to regional development. It will take a lot of time to abandon seeing this issue as ethnic, and even among scientists, the essentialism in ethnicity is, in this case, still present.

Sources of major ethnic change are usually anchored in specific time periods in Central European history in the $20^{\text {th }}$ century. In our analysis, we presupposed these time periods to be salient in the ethnic landscape evolution (1918, 1938), but we saw that the changes had unforeseen manifestations. For example, the ethnic changes in $1880-1910$ are stereotypically perceived as periods of the vast ethnic destruction of Slovak nationhood ${ }^{10}$; however, ethnic changes in Slovakia had a much bigger impact on the 1921 and 1950 censuses. In particular, 1930 to 1950 was the most turbulent period in Slovakian ethnic history, with most changes in Slovakian regions from that time heading towards ethnic homogenization. Also, the cumulative ethnic diversity change index proved that, between 1910 and 1921, the change was at a value of 6.9, and in $1930-$ 1950 at 22.9. Both intervals (1910 - 1921 and $1930-1950)$, however, saw the most significant momentum in regional ethnic landscape history. (See Figure 7)

\footnotetext{
${ }^{10}$ The idea of diverse attitudes toward censuses for 1910 and 1921 is outlined, for example, in Holec (2012: 126), wherein he paraphrases opinions on unjust Hungarian statistics and census data and 'correct' Czechoslovak census ethnicity data.
} 
Figure 7: Intercensal interval of the biggest change in ethnic diversity in the regions of Slovakia

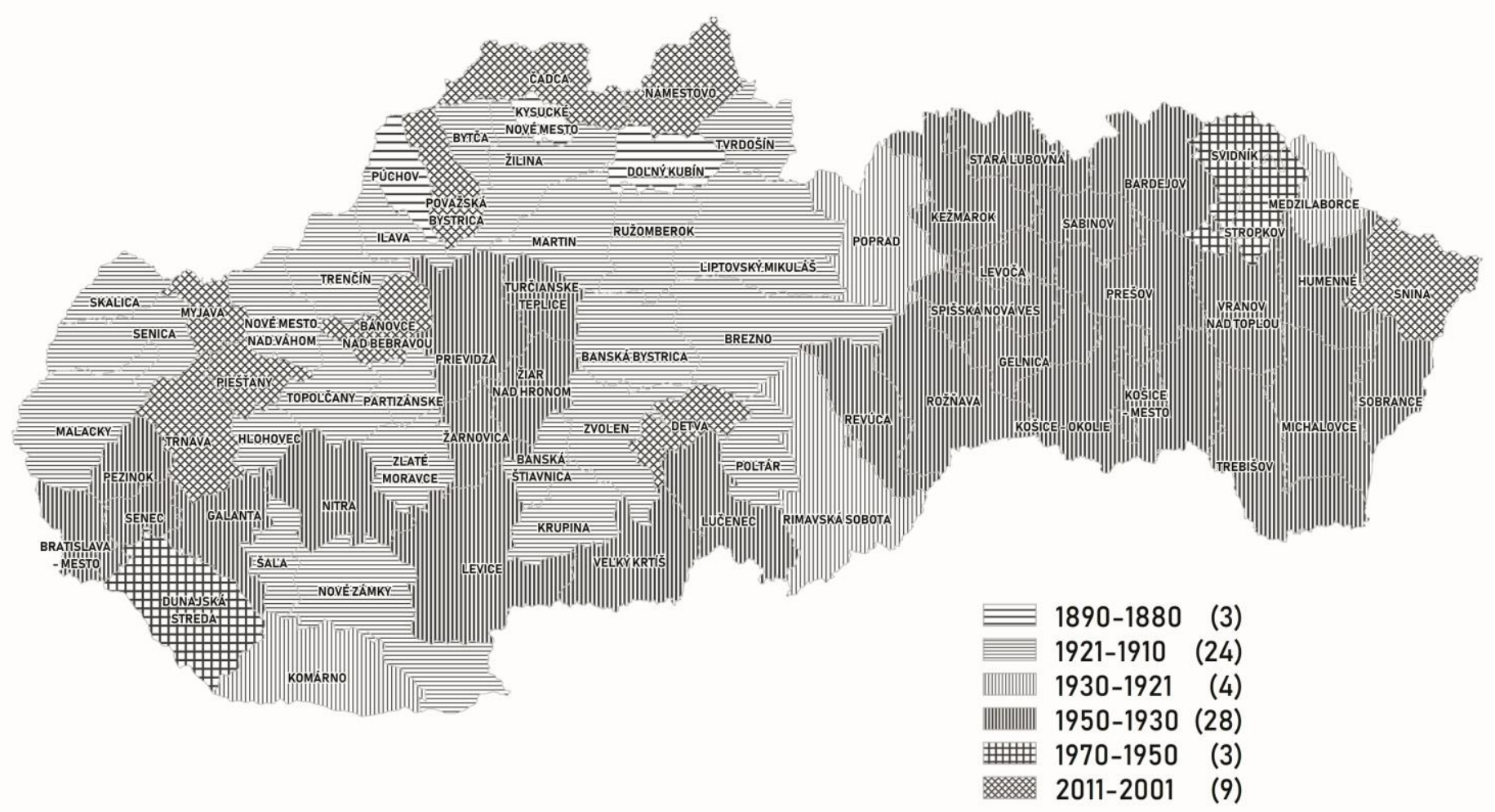

Source: Majo et al. 2017, own calculations. 
Ethnically diverse regions in Slovakia are regions we still know very little about. Usually, we tend to see diversity connected to conflict that can even have its national dimensions. As D. Kusá (2009: 64-65) said, "in ethnically mixed regions it is common when "small histories" of people sharing one common local space, clash with "big histories". Not due to the existential cleavage among them, but due to the fact that the ethnic platform is very tempting to trigger political fights and national leaders sometimes become involved in local conflicts if they present themselves in the light of a fight between two nations." This was not the aim of this article, to find the spaces of conflict, although they exist, but to find and delimit the areas of diversified ethnicity that underwent salient changes in the $20^{\text {th }}$ century.

Juraj Majo is a human geographer and demographer currently employed as an assistant professor at the Department of Human Geography and Demography at the Comenius University in Bratislava. His research interests are geography and demography of ethnic and religious group, geography of religions, and cultural geography.

\section{REFERENCES}

ALGAN, Y. - HÉMET, C. - LAITIN, D. D., 2016: The Social Effects of Ethnic Diversity at the Local Level: A Natural Experiment with Exogeneous Residential Allocation. Journal of Political Economy 124, 3, pp. 696-733. DOI: 10.1086/686010

AREL, D., 2004: Language Categories in Censuses: Backward- or Forward-Looking? In: Kertzer, I. D. - Arel. D. (eds): Census and Identity. The Politics of Race, Ethnicity, and Language in National Censuses. Cambridge: Cambridge University Press, pp.92-120.

ARNAUT, K., 2012: Super-Diversity: Elements of an Emerging Perspective. Diversities 14, 2, pp. 1-16.

BAČOVÁ, V., 1992: Národ a etnicita - nahliadnutie do niektorých koncepcií. Sociológia 24, 1-2, pp. 17-24.

BENKOVIČOVÁ, L., 2014: SODB 2011 - výnimočné sčítanie / The 2011 Population and Housing Census - an extraordinary census. In: Juhaščíková, I., Štukovská, Z. (eds): Potrebuje ešte Slovensko po sčítaní 2011 d'alší census? Bratislava: Štatistický úrad SR, pp. $10-18$.

BOTÍK, J., 2006: Etnická história Slovenska. Bratislava: Lúč.

BROMLEJ, V. J., 1980: Etnos a etnografia. Bratislava: Veda SAV.

BROWN, K. G. - LANGER, A., 2010: Conceptualizing and Measuring Ethnicity. Oxford Development Studies 38, 4, pp. 411-436. DOI: 10.1080/13600818.2010.525629

BUČEK, J., 2001: Responding to Diversity: Solutions at the Local Level in Slovakia. In: Bíró, A. - Kovács, P. (eds): Diversity in Action. Local Public Management of MultiEthnic Communities in Central and Eastern Europe. Budapest: Local Government and Public Service Reform Initiative, Open Society Institute, pp. 273-306.

COLLIER, P. - HONOHAN, P. - MOENE, K. O., 2001: Implications of Ethnic Diversity. Economic Policy 16, 32, pp. 128-166. DOI: 10.1111/1468-0327.00072 
CRUL, M., 2016: Super-Diversity vs. Assimilation: How Complex Diversity in MajorityMinority Cities Challenges the Assumptions of Assimilation. Journal of Ethnic and Migration Studies 42, 1, pp. 54-68. DOI: 10.1080/1369183X.2015.1061425

CZIBULKA, Z., 1999: Az állampolgárság, a nemzetiség, az anyanyelv és a vallás összeírásának népszámlálási lehetőségei és problémái. In Kepecs, J. (ed): Népszámlálás az ezredfordulón 2. Budapest: Központi statisztikai hivatal, pp. 27-51.

DULEBA, A., 2005: Minulé i súčasné otázky rusínskej identity. In: Marušiak, J. - Ferencová, M. (eds.): Teoretické prístupy k identitám a ich praktické aplikácie. Bratislava: Ústav politických vied SAV a VEDA SAV, pp. 107-118.

ĎURČEK, P. - ŠPROCHA, B., 2017: Centrá a zázemia funkčných mestských regiónov na Slovensku optikou kohortnej plodnosti. Geografický časopis 69, 3, pp. 225-244.

EASTERLEY, W. - LEVINE, R., 1997: Africa's Growth Tragedy: Policies and Ethnic Divisions. The Quarterly Journal of Economics 112, 4, pp. 1203-1250. DOI: 10.1162/003355300555466

ERIKSEN, T. H., 2008: Sociální a kulturní antropologie. Př́ibuzenství, národnostní př́slušnost, rituál. Praha: Portál.

FAIST, T., 2015: Diversity Unpacked. From Heterogeneities to Inequalities. In: Vertovec, S. (ed.): Routledge International Handbook of Diversity Studies. Oxon, New York: Routledge, pp. 265-273.

GRANATIER, A., 1930: Etnické rozhranie slovensko-mad'arské. Bratislava: Slovenská odbočka národnej rady Čs.

GUEST, A. M. - WEED, J. A., 1976: Ethnic Residential Segregation: Patterns of Change. The American Journal of Sociology 81, 5, pp. 1088-1111. DOI: 10.1086/226186

GYURGYÍK, L., 2008: Zmeny v demografickej, sídelnej a sociálnej štruktúre Mad’arov na Slovensku. In: Fazekas, J. - Hunčík, P. (eds): Mad'ari na Slovensku (1989 - 2004). Súhrnná správe od zmeny režimu po vstup do Európskej únie. Šamorín: Fórum inštitút pre výskum menšín, pp. 155-198.

HÄUFLER, V., 1976: Národnostní poměry České socialistické republiky. Praha: Academia.

HOLEC, R., 2012: Úvahy k fenoménu mad'arizácie pred rokom 1918. In: Bystrický, V. Kováč, D. - Pešek, J. et al. (eds.): Klúčové problémy moderných slovenských dejín 1848 - 1992. Bratislava: Veda SAV, pp. 80-135.

IRA, V., 1996: Etnická a religiózna štruktúra obyvatel'stva východného Slovenska a percepcia etnických a religióznych napätí. Geografický časopis 48, 1, pp.13-34.

JEHLIČKA, P. - SÝKORA, L. 1991: Stabilita regionální podpory tradičních politických stran v českých zemích (1920 - 1990). Sborník České geografické společnosti 96, 2, pp. 81-95.

KISS, C. G., 1992: Národnostné menšiny v strednej Európe - definície a typológie. In: Plichtová, J. (ed.): Minority v politike. Kultúrne a jazykové práva. Bratislava: Československý výbor Európskej kultúrnej nadácie, pp. 61-65.

KOREC, P., 2014: Lagging Regions of Slovakia in the Context of their Competitiveness. Rozwoj Regionalny i Polityka Regionalna 25, 2014, pp. 113-134. DOI: 10.14746/rrpr.2014.25.07

KOREC, P. - RUSNÁK, J., 2016: Zaostávajúce regióny Slovenska v kontexte nového (európskeho) regionalizmu. Geografické informácie 20, 2, pp. 216-230. DOI: 10.17846/GI.2016.20.2.216-230

KOVÁČ, D, 2009: Formovanie identít v stredoeurópskom priestore. In: Kiliánová, G. Kowalská, E. - Krekovičová, E. (eds.): My a tí druhí v modernej spoločnosti. Konštrukcie a transformácie kolektívnych identít. Bratislava: Veda SAV, pp. 237-241. 
KUSÁ, D., 2009: Úloha kolektívnej pamäti v procese etnickej mobilizácie. In: Drál', P. Findor, A. (eds.): Ako skúmat' národ. Devät' štúdií o etnicite a nacionalizme. Brno: Tribun EU, pp. 57-78.

LÁŠTICOVÁ, B., 2009: Slováci a/alebo Európania? Kolektívne identity, sociálne reprezentácie a spoločenská zmena. In: Drál', P. - Findor, A. (eds.): Ako skúmat' národ. Devät' štúdií o etnicite a nacionalizme. Brno: Tribun EU, pp. 35-56.

LIEBERSON, S. 1969: Measuring Population Diversity. American Sociological Review, 34, 6, pp. 850-862. DOI: $10.2307 / 2095977$

MAJO, J., 2013: Vybrané charakteristiky transformácie religiozity na Slovensku v rokoch 1950 - 2001 vo vzt’ahu k sekularizácii. Geografický časopis 65, 3, pp. 217-234.

MAJO, J., 2012: Historicko - demografický lexikón obcí Slovenska 1880 - 1910. Bratislava: Štatistický úrad SR.

MAJO, J. - HORŇÁK, M., 2007: Ethnic Diversity of the Population of Slovakia. Europa XXI. Regional Development in Central Europe - Cohesion or Competitiveness 16, 2007, pp. 191-198.

MAJO, J. - ŠPROCHA, B., 2016: Storočie populačného vývoja Slovenska II - populačné štruktúry. Bratislava: Infostat, CSPV SAV, Univerzita Komenského v Bratislave.

MAJO, J. - TÍŽIK, M. - ŠKÁPIK, P. 2017: Prehl'ad etnicity obyvatel'stva obcí Slovenska v sčítaniach 1880-2011. Slovenský archív sociálnych dát (dataset). Bratislava: Sociologický ústav SAV.

MAZÚR, E., 1974: Národnostné zloženie. In: kol. autorov: Slovensko, L’ud I.. Bratislava: Obzor, pp. 440-462.

MÉSÁROŠ, J., 2004: Deformácie vo využívaní údajov sčítania l'udu v novodobých slovensko-mad'arských sporoch. In: Mésároš, J.: Zložité hl'adanie pravdy o slovenských dejinách. Bratislava: Veda SAV, pp. 196-210.

MUSTERD, S. - VAN KEMPEN, R., 2009: Segregation and Housing of Minority Ethnic Groups in Western European Cities. Tijdschrift voor economische en sociale geografie, 100, 4, pp. 559-566. DOI: 10.1111/j.1467-9663.2009.00558.x

MUŠINKA, A. - ŠKOBLA, D. - HURRLE, J. - MATLOVIČOVÁ, K. - KLING, J., 2013: Atlas rómskych komunít na Slovensku. Bratislava: Regionálne centrum Rozvojového program OSN pre Európu a Spoločenstvo nezávislých štátov.

OKEDIJI, T. O., 2005: The Dynamics of Ethnic Fragmentation - a Proposal for an Expanded Measurement Index. The American Journal of Economics and Sociology 64, 2, pp. 637-662. DOI: 10.1111/j.1536-7150.2005.00382.x

PATIL, G. P. - TAILLE, C., 1982: Diversity as a Concept and its Measurement. Journal of the American Statistical Association, 77, 379, pp. 548-556.

PIASECKI, E., 1964: Chyrakterystyka liczebności ludów świata i próba analizy zwartości etnicznej terzytoriów. Czasopismo geograficzne 35, 73, pp. 73-85.

PIEKUT, A. - REES, P. - VALENTINE, G. - KUPISZEWSKI, M., 2012: Multidimensional Diversity in Two European Cities: Thinking Beyond Ethnicity. Environment and Planning 44, pp. 2988-3009. DOI: 10.1068/a4512

PODOBA, J., 2009: Identita a moc: etnický konflikt v kontexte transformačných procesov. In: Kiliánová, G. - Kowalská, E. - Krekovičová, E. (eds.): My a tí druhí v modernej spoločnosti. Konštrukcie a transformácie kolektívnych identít. Bratislava: Veda SAV, pp. 554-585.

POSNER, D. N., 2004: Measuring Ethnic Fractionalization in Africa. American Journal of Political Science 48, 4, pp. 849-863. DOI: 10.1111/j.0092-5853.2004.00105.x 
PRICE, P. L., 2014: Race and Ethnicity: Geographies of Diversity. Progress in Human Geography 39, 4, pp. 1-10. DOI: 10.1177/0309132514535877

SIWEK, T., 1996: Česko - polská etnická hranice. Ostrava: Filosofická fakulta Ostravské univerzity.

SCHNEIDER, G. - WIESEHOMEIER, N., 2010: Diversity, Conflict and Growth: Theory and Evidence. Diversity 2010, 2, pp. 1097-1117. DOI:10.3390/d2091097

SCHÖPFLIN, G., 1996: Language and Ethnicity in Central and Eastern Europe: Some Theoretical Aspects. Politička misao 33, 5, pp. 99-107.

STILLWELL, J. - PHILLIPS, D., 2006: Diversity and Change: Understanding the Ethnic Geographies of Leeds. Journal of Ethnic and Migration Studies 32, 7, pp. 1131-1152. DOI: $10.1080 / 13691830600821851$

SVETOŇ, J., 1941: Slováci v Mad’arsku. Príspevky k otázke štatistickej mad’arizácie. Bratislava: Vedecká spoločnost' pre zahraničných Slovákov.

ŠATAVA, L., 1994: Národnostní menšiny v Evropě. Praha: Ivo Železný.

ŠPROCHA, B., 2014: Reprodukcia rómskeho obyvatel'stva na Slovensku a prognóza jeho populačného vývoja. Bratislava: Infostat, Výskumné demografické centrum.

ŠPROCHA, B., 2014a: Populačný vývoj národnostných menšín na Slovensku po druhej svetovej vojne. In: Tišliar, P. - Šprochová, T. (eds): Populačné štúdie Slovenska, 4, Bratislava: Muzeológia a kultúrne dedičstvo, o.z., pp. 185-216.

ŠOLTÉS, P., 2009: Tri jazyky, štyri konfesie. Etnická a konfesionálna pluralita na Zemplíne, Spiši a Šariši. Bratislava: Historický ústav SAV.

ŠUTAJ, Š., 2012: Mad'arská menšina na Slovensku v 20. storočí. Bratislava: Kalligram.

ŠUTAJ, Š. (ed.), 2005: Národ a národnosti na Slovensku v transformujúcej sa spoločnosti vzt'ahy a konflikty. Prešov: Universum.

ŠVORC, P., 2005: Vol'by 1920, sčítanie obyvatel'stva 1921 a krajinská hranica. In: Švorc, P. - Harbul'ová, L. - Schwarz, K. (eds.): Národnostná otázka v strednej Európe v rokoch 1848-1938. Prešov: Universum, pp.185-197.

VAŇO, B. 2001: Demografická charakteristika rómskej populácie v SR. Bratislava: Infostat - Výskumné demografické centrum.

VERTOVEC, S., 2015: Introduction. Formulating Diversity Studies. In: Vertovec, S. (ed.): Routledge International Handbook of Diversity Studies. Oxon, New York: Routledge, pp. 1-20.

VERTOVEC, S., 2007: Super-Diversity and its Implications. Ethnic and Racial Studies, 30, 6, pp. 1024-1054. DOI: 10.1080/01419870701599465

WARF, B. - VINCENT, P., 2007: Religious Diversity Across the Globe: A Geographic Exploration. Social \& Cultural Geography, 12, 4, pp. 597-613. DOI: 10.1080/14649360701529857

WHITE, M., 1986: Segregation and Diversity Measures in Population Distribution. Population Index, 52, 2, pp. 198-221.

WONG, D., S. W. - SHAW, S. L., 2011: Measuring Segregation: An Activity Space Approach. Journal of Geographical Systems, 13, 2, pp. 127-145. DOI: 10.1007/s10109010-0112-x

YEOH, K. K., 2003: Phenotypical, Linguistic, or Religious? On the Concept and Measurement of Ethnic Fragmentation. Malaysian Journal of Economic Studies, 40, 1-2, pp. 23 47. 